\title{
The Relationships between Arterial Oxygen Flow Rate, Oxygen Binding by Hemoglobin, and Oxygen Utilization
} after Myocardial Infarction

\author{
Marshall A. Lichtman, Jules Cohen, Jerald A. Young, \\ APril A. WhitbecK, and Marion MURPhY \\ From the Departments of Medicine and of Radiation Biology and Biophysics, \\ University of Rochester School of Medicine, Rochester, New York 14642
}

A в S T R A C T The interrelationships of arterial oxygen flow rate index, oxygen binding by hemoglobin, and oxygen consumption have been examined in patients with acute myocardial infarction. Proportional extraction of oxygen increased in close association with decreasing oxygen flow rate, and hence, whole body oxygen consumption was constant over nearly a threefold variation in arterial oxygen flow rate. A reduction in hemoglobin-oxygen affinity at in vivo conditions of $\mathrm{pH}, \mathrm{P}_{\mathrm{CO}_{2}}$ and temperature also occurred in proportion to the reduction in arterial oxygen flow rate. Therefore, the increased proportional removal of oxygen from arterial blood at low oxygen flow rates, required to maintain oxygen consumption, may have been facilitated by the reduced affinity of hemoglobin for oxygen at in vivo conditions. However, the decrease in affinity did not appear to explain more than $30-40 \%$ of the increased extraction.

Respiratory alkalosis was a frequent occurrence in these patients and 2,3-diphosphoglycerate was positively associated with blood $\mathrm{pH}$ as well as with the time-averaged proportion of deoxyhemoglobin in arterial and venous blood.

Hemoglobin-oxygen affinity measured at standard conditions and the mixed venous oxygen saturation were equally good indicators of reduced arterial oxygen flow rate in patients without shock. However, $\mathrm{S}_{\mathrm{O}_{2}}$ is more easily measured and is a more useful indicator of reduced oxygen flow rate, since its relationship to oxygen flow appears to be independent of affinity changes and time.

Dr. Lichtman is a Scholar of the Leukemia Society of America. Dr. Cohen was a recipient of Research Career Development Award No. K3HL 17885.

Recciced for publication 17 October 1973 and in rezised form 14 March 1974

\section{INTRODUCTION}

Decreased hemoglobin concentration, oxygen saturation of hemoglobin, or blood flow can result in a decrease in systemic arterial oxygen flow, an increase in red cell 2,3-diphosphoglycerate $(2,3-D P G)^{1}$ and a decrease in hemoglobin's affinity for oxygen at standard conditions of measurement in vitro $(1,2)$. The first two causes of reduced oxygen flow, anemia (1-4) and hypoxia (1, 2, 4-6) have been studied extensively. Few studies have been made of red cell adaptive changes during low blood flow states. Woodson, Torrance, Shappell, and Lenfant (7) and Metcalfe, Dhindsa, Edwards, and Mourdjinis (8), studying patients with chronic cardiac decompensation, have shown that reduced cardiac output is associated with elevated red cell 2,3-DPG (7) and decreased hemoglobin-oxygen affinity (7, 8). Kostuk, Suwa, Bernstein, and Sobel observed decreased affinity after acute myocardial infarction (9). However, $P_{50}$ did not correlate with cardiac index $(\mathrm{CI})$ or with red cell 2,3-DPG, leaving the pathogenesis of the affinity change in doubt.

Our studies were undertaken to examine in further detail (a) the effect of acute myocardial infarction on oxygen binding by hemoglobin at in vivo conditions; (b) the relationship of changes in blood flow and arterial oxygen content to changes in affinity; $(c)$ the role of altered $\mathrm{pH}$, oxygen saturation, and red cell 2,3-DPG content in the modulation of the affinity changes; (d) the role of changes in hemoglobin-oxygen affinity in the maintenance of whole body oxygen utilization; and $(e)$ the usefulness of changes in red cell 2,3-DPG

1 Abbreitiations used in this paper: BE, basic excess; CI, cardiac index; 2,3-DPG, 2,3-diphosphoglycerate; HFI, hemoglobin flow index; MIRU, Myocardial Infarction Research Unit; OFI, oxygen flow index; ta, time-averaged. 
content and oxygen binding by hemoglobin as indexes of severity of myocardial functional impairment and of clinical status.

\section{METHODS}

Study population. 62 consecutive patients ( 44 men and 18 women, aged 30-66) with acute myocardial infarction were studied in the Myocardial Infarction Research Unit (MIRU) of the Strong Memorial Hospital. History, electrocardiographic changes, and elevated levels of serum glutamicoxaloacetic transaminase, lactic dehydrogenase, and creatine phosphokinase confirmed the diagnosis of acute myocardial infarction in 61 of the 62 patients. 33 subjects had anterior or anterolateral wall infarction and 26 had diaphragmatic infarction. One patient had unstable angina without infarction. In two patients, although infarction was definite from history and changes in serum enzymes, the site of the infarct could not be determined electrocardiographically.

Of the total 62 patients studied, 13 consecutive patients were studied in detail, prospectively. Data from the 49 additional patients were obtained retrospectively from measurements made on all patients admitted to the MIRU. All patients were classified as to the severity of clinical disease as described by Interiano, Hyde, Hodges, and $\mathrm{Yu}$ (10). At entrance to the MIRU, 19 patients were in class I (no evidence of congestive failure); 24 in class II (rales and third heart sound); 12 in class III (pulmonary edema); and 5 in class IV (cardiogenic shock). These clinical classifications were made without knowledge of the results of the oxyhemoglobin affinity studies, and were independently reviewed and confirmed.

Hemodynamic studies. A Swan-Ganz balloon catheter was passed to the pulmonary artery and an 18-gauge long-dwell catheter was placed in the brachial artery in each patient. Pulmonary artery, pulmonary capillary wedge, and systemic artery pressures were monitored through either Statham p37 or Micron Instruments MP-15 pressure transducers (Statham Instruments, Inc., Oxnard, Calif.; Micron Instruments, Inc., Los Angeles, Calif.) and recorded on a Brush direct writer. (Brush Instruments Div., Cleveland, Ohio). Cardiac output was determined by either indicator dilution or thermal dilution technique. Indicator dilution curves were inscribed after $2 \mathrm{ml}$ of indocyanine green dye was injected into the pulmonary artery and blood was withdrawn from the brachial artery with a Harvard constant withdrawal pump (Harvard Apparatus Co., Inc., Millis, Mass.). A Gilford densitometer was used to measure dye concentration (Gilford Instrument Laboratories, Inc., Oberlin, Ohio). When output was measured by thermal dilution, injections of $10 \mathrm{ml}$ of iced saline were made into the right atrium and temperature monitored by a catheter-tipped thermister positioned in the pulmonary artery. All outputs were measured in duplicate. In all cases, extrapolation of curves and integration of areas beneath curves were performed by a Xerox Sigma 3 computer (Xerox Corp., El Segundo, Calif.).

Blood gas studies. Blood samples from all patients were collected either from a right atrial or from a pulmonary artery catheter in the presence of heparin. Samples were obtained during the first 4 days after admission to the MIRU.

In the 13 patients studied prospectively, an Instrumentation Laboratory (Instrumentation Laboratory, Inc., Lexington, Mass.) gas-mixing module (model 2081), oxygen monitor (model 2083), and tonometer (model 137) were used to adjust oxygen tension $\left(\mathrm{P}_{\mathrm{O}_{2}}\right)$ to between 15 and 60 torr while carbon dioxide tension $\left(\mathrm{P}_{\mathrm{CO}_{2}}\right)$ was maintained at $40 \pm 0.2$ torr. The oxygen saturation of blood $\left(\mathrm{S}_{\mathrm{O}_{2}}\right)$ was measured with a model 182 cooximeter. $\mathrm{pH}, \mathrm{P}_{\mathrm{O}_{2}}$, and $\mathrm{P}_{\mathrm{CO}_{2}}$ were determined with a model $113 \mathrm{pH}$-gas analyzer. Each determination was made in duplicate. The $\mathrm{P}_{\mathrm{O}_{2}}$ at which $50 \%$ of hemoglobin was saturated with oxygen at $37^{\circ} \mathrm{C}, \mathrm{pH}=7.4, \mathrm{P}_{\mathrm{CO}_{2}}=40$ torr $\left(\mathrm{P}_{50}\right.$ std) was derived from a least-squares analysis of the experimental points. Base excess (BE) was calculated from the blood $\mathrm{pH}$ and $\mathrm{P}_{\mathrm{CO}_{2}}$, as suggested by Severinghaus (11).

In the 49 patients studied retrospectively, $\mathrm{pH}, \mathrm{P}_{\mathrm{O}_{2}}$ and $\mathrm{P}_{\mathrm{CO}_{2}}$ were measured with an Instrumentation Laboratory model 113 blood gas analyzer and $\mathrm{S}_{\mathrm{O}_{2}}$ was determined either by the manometric method of Van Slyke and Neill (12) or with an American Optical Corp. (Southbridge, Mass.) macroreflection oximeter. The $\mathrm{P}_{\mathrm{O}_{2}}$ of the pulmonary artery samples was between 25 and 50 torr. The $\mathrm{P}_{50}$ std at $37^{\circ} \mathrm{C}$, $\mathrm{pH}=7.40, \mathrm{P}_{\mathrm{CO}_{2}}=40$ torr was determined from the $\mathrm{P}_{\mathrm{O}_{2}}$ and $\mathrm{S}_{\mathrm{O}_{2}}$ of the pulmonary artery blood by an extrapolation to $\mathrm{P}_{50}$ made on the assumption that the observed $\mathrm{P}_{\mathrm{O}_{2}}$ and $\mathrm{S}_{\mathrm{O}_{2}}$ were on a sigmoid curve that paralleled the standard oxyhemoglobin dissociation curve.

Calculation of $\mathrm{Hb} / \mathrm{HbO}_{2}$ time-averaged (ta) ratio, hemoglobin flow index, oxygen content, oxygen flow index, oxygen consumption and $P_{50}$ in vivo. The ratio of the proportion of deoxyhemoglobin $(\mathrm{Hb})$ to oxyhemoglobin $\left(\mathrm{HbO}_{2}\right)$ was calculated in systemic and pulmonary arterial blood. Based on the estimate that $40 \%$ of the blood volume is distributed on the arterial side of the circulation and $60 \%$ on the venous side, the following formula was used to derive an estimate of the time-averaged ratio:

$$
\mathrm{Hb} / \mathrm{HbO}_{2}(\mathrm{ta})=0.4\left(\mathrm{Hb}_{\mathrm{a}} / \mathrm{HbO}_{2 \mathrm{a}}\right)+0.6\left(\mathrm{Hb}_{\overline{\mathrm{v}}} / \mathrm{HbO}_{2 \overline{\mathrm{v}}}\right) .
$$

Hemoglobin flow index (HFI) was calculated by the formula : $\mathrm{HFI}\left(\mathrm{g} / \mathrm{min}\right.$ per $\left.\mathrm{m}^{2}\right)=\mathrm{Hb}(\mathrm{g} /$ liter $) \times \mathrm{CI}\left(\right.$ liter $/ \mathrm{min}$ per $\left.\mathrm{m}^{2}\right)$. Oxygen content of blood was calculated by the formula: $\mathrm{C}_{\mathrm{O}_{2}}(\mathrm{ml} /$ liter $)=\mathrm{Hb}(\mathrm{g} /$ liter $)$

$$
\times 1.39(\mathrm{ml} / \mathrm{g}) \times \mathrm{S}_{\mathrm{O}_{2}} \text { (proportional saturation). }
$$

Oxygen flow index (OFI) was calculated by the formula:

OFI $\left(\mathrm{ml} / \mathrm{min}\right.$ per $\left.\mathrm{m}^{2}\right)=\mathrm{C}_{\mathrm{O}_{2}}(\mathrm{ml} /$ liter $)$ $\times \mathrm{CI}\left(\right.$ liter $/ \mathrm{min}$ per $\left.\mathrm{m}^{2}\right)$

Oxygen consumption was calculated from the formula:

$$
\dot{\mathrm{V}}_{\mathrm{O}_{2}}\left(\mathrm{ml} / \mathrm{min} \text { per } \mathrm{m}^{2}\right)=\mathrm{OFI}_{\mathrm{a}}-\mathrm{OFI}_{\overline{\mathrm{v}}}
$$

$P_{50}$ std was converted to an estimate of the $P_{50}$ present in vivo in arterial blood by the formula:

$$
\begin{aligned}
\log \mathrm{P}_{50} \text { i.v. }=\log \mathrm{P}_{50} \mathrm{std}+ & 0.48(7.40-\mathrm{pH}) \\
+ & 0.0013(\mathrm{BE})+0.024\left(\mathrm{~T}-37^{\circ} \mathrm{C}\right) .
\end{aligned}
$$

$\mathrm{pH}$ and $\mathrm{BE}$ were those measured in arterial blood

Chemical determinations. Blood hemoglobin was measured in duplicate by the cyanmethemoglobin method and hematocrit was measured in triplicate in an International Equipment Company (Needham Heights, Mass.) microhematocrit centrifuge at approximately $10,000 \mathrm{~g}$ for $5 \mathrm{~min}$. Red cell 2,3-DPG was measured by the method of Rose and Liebowitz (13).

Statistical methods. Means, variances, linear regressions, simple, multiple, and partial correlation coefficients, confidence and tolerance intervals, and significance tests were performed with formulae entered into a Wang 600 programmable calculator (Wang Laboratories, Inc., Tewksbury, Mass.) The equations for statistical tests were obtained from three sources (14-16). 


\section{RESLITS}

Correlation of components of arterial oxygen flow with oxygen-hemoglobin affinity. The determinants of sy:temic arterial OFI $\left(\mathrm{OFI}_{\mathrm{a}}\right)$ are presented in Fig. 1. They include those elements that determine $\mathrm{Ca}_{0}$, (i.e. oxygen capacity and saturation of arterial blood). as well as the rate of systemic blood flow, i.e. CI. Each component of $\mathrm{OFI}_{a}$ has been examined for its separate influence on oxygen binding by hemoglobin in the 13 subjects studied prospectively. The data gathered on each patient at each point of study are presented in Table I.

$\mathrm{P}_{50}$ std was moderately, although significantly correlated with each of the three components of oxygen flow index; $\mathrm{Hb}, \mathrm{Sa}_{2}$, and CI (Table II). $\mathrm{OFI}_{a}$, i.e. the product of $\mathrm{Hb}, \mathrm{Sa}_{2}$ and $\mathrm{CI}$, representing the summation of oxygen availability as blood approaches tissue capillaries, was more strongly correlated with $\mathrm{P}_{50}$ std than was its components. However, the association of $\mathrm{Ca}_{2}$, the product of $\mathrm{Hb}$ and $\mathrm{Sa}_{2}$, with $\mathrm{P}_{50}$ std was as strong as that of $\mathrm{OFI}_{a}$ with $\mathrm{P}_{50}$ (Fig. 2). In view of this, we considered the possibility that CI was correlated with $\mathrm{P}_{50}$ std as a result of a dependence of $\mathrm{Cl}$ on $\mathrm{Ca}_{\mathrm{O}_{2}}$. However, the correlation of $\mathrm{CI}$ with $\mathrm{Ca}_{2}$ was weak and not significant (Table II). Moreover, $\mathrm{P}_{50}$ std correlated with $\mathrm{Ca}_{\mathrm{O}_{2}}(r=-0.68, P<0.001)$ and with CI $(r=-0.47, P<0.05)$, when the effect of the alternate variable was held constant with partial correlation statistics. Hence, $\mathrm{Ca}_{2}$ or $\mathrm{CI}$ could influence $\mathrm{P}_{50}$ std independent of its contribution to $\mathrm{OFI}_{\mathrm{a}}$. Therefore, we computed the combined influence of these two variables on $\mathrm{P}_{50}$ std with multiple regression analysis. The multiple correlation of $\mathrm{P}_{50}$ std with both $\mathrm{Ca}_{2}$ and CI was stronger $(r=0.76)$ than that of $\mathrm{P}_{50}$ std with $\mathrm{OFI}_{\mathrm{a}}(r=-0.71)$, although the difference did not reach statistical significance.

Since any change in $\mathrm{P}_{50}$ that respresents a response to low flow might be delayed, we also studied the relationship between $P_{50}$ std and the determinants of arterial oxygen flow measured on the preceding hospital day. The correlations were virtually identical to those relating $\mathrm{P}_{50}$ to flow state and oxygen content measured on the same day, because $\mathrm{CI}$ and $\mathrm{Ca}_{\mathrm{O}_{2}}$ were relatively similar within each patient over the period of study, and the studies were performed in nearly all cases relatively long after the onset of symptoms $(>24 \mathrm{~h})$ (Table I).

Mechanism of altered affinity in response to changing arterial oxygen flow. Although Kostuk and coworkers failed to find a correlation between $\mathrm{P}_{50}$ after myocardial infarction and red cell 2,3-DPG level (9), a basis for the affinity changes in our subjects was sought in the well-established dependence of $P_{50}$ std on red

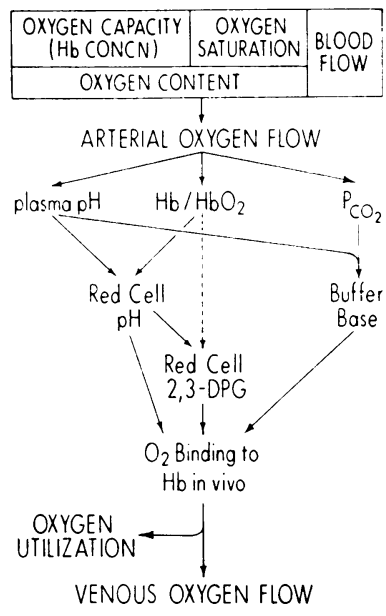

FIGLRE 1 The major components of arterial oxygen flow $\left(\mathrm{Hb}, \mathrm{S}_{\mathrm{O}_{2}}\right.$ and $\left.\mathrm{CI}\right)$ are shown. The possible role of $\mathrm{pH}$ and $\mathrm{Hb} / \mathrm{HbO}_{2}$ ratio in mediating the effects of reduced oxygen flow on red cell 2,3-DPG is depicted. Increased blood $\mathrm{pH}$ and decreased $\mathrm{P}_{\mathrm{CO}_{2}}$ appear to be frequent sequelae of decreased arterial oxygen flow. The major factors contributing to the affinity of hemoglobin for oxygen in vivo, i.e. red cell $\mathrm{pH}$, 2,3-DPG, and the $\mathrm{pH}$-independent direct effect of $\mathrm{CO}_{2}$ are shown. Red cell $\mathrm{pH}$ is closely dependent on blood (plasma) $\mathrm{pH}$. Buffer base derived from the $\mathrm{pH}$ and $\mathrm{P}_{\mathrm{CO}_{2}}$ can be used to represent the $\mathrm{pH}$-independent effect of $\mathrm{P}_{\mathrm{CO}_{2}} \cdot \mathrm{Hb} / \mathrm{HbO}_{2}$ ratio can influence the intracellular $\mathrm{pH}$ and may increase total cellular 2,3-DPG by its effects on the level of free 2,3-DPG content. The difference between arterial and venous oxygen flow represents oxygen consumption.

cell 2,3-DPG. We found $P_{50}$ std to be highly correlated with red cell 2,3-DPG $(r=0.87, P<0.001)$ (Fig. 3A).

Relationship of red cell 2,3-DPG and $P_{50}$ std to blood $\mathrm{pH}$ and $\mathrm{Hb} / \mathrm{HbO}_{2}$ (ta). Intraerythrocytic $\mathrm{pH}$ is an important determinant of red cell glycolytic rate (17) and also of the steady-state level of 2,3-DPG (18). Two important mechanisms may initiate an alteration in red cell $\mathrm{pH}$ : one is a change in plasma $\mathrm{pH}$, since red cell $\mathrm{pH}$ is directly dependent on plasma $\mathrm{pH}$ (19), and a second is an increase in the ratio of deoxygenated to oxygenated hemoglobin (20). The latter effect occurs because $\mathrm{Hb}$ binds protons more avidly than $\mathrm{HbO}_{2}$. The effect of such a change in intracellular $\mathrm{pH}$ is dual. An instantaneous result on oxygen binding by hemoglobin is mediated by the Bohr effect (21). A later effect of red cell $\mathrm{pH}$ appearing after $36-48 \mathrm{~h}$ is an alteration in red cell 2,3-DPG content (22). Reduction in $\mathrm{Hb} / \mathrm{HbO}_{2}$ ratio also has a $\mathrm{pH}$-independent delayed effect that may further influence red cell 2,3-DPG content. Deoxygenated hemoglobin has a higher affinity for 2,3-DPG than $\mathrm{HbO}_{2}$. By increasing the $\mathrm{Hb} / \mathrm{HbO}_{2}$ ratio, free 2,3-DPG is decreased and acceleration of 2,3-DPG synthesis occurs (20). Since $\mathrm{Hb} / \mathrm{HbO}_{2}$ ratio will be markedly different in arterial and venous circulations, a weighted average of the two ratios was 
TABLE I

Component Variables for Calculation of Oxygen Flow, Oxygen Consumption

\begin{tabular}{|c|c|c|c|c|c|c|c|c|c|c|c|c|c|}
\hline $\begin{array}{c}\text { Subject } \\
\text { and } \\
\text { class }\end{array}$ & $\begin{array}{c}\text { Date of } \\
\text { study }\end{array}$ & $\begin{array}{c}\text { Time } \\
\text { from } \\
\text { onset of } \\
\text { symptoms }\end{array}$ & $\mathrm{Hb}$ & $\mathrm{PaO}_{2}$ & $\mathrm{SaO}_{2}$ & $\mathrm{CaO}_{2}$ & $\mathrm{P} \overline{\mathrm{v}} \mathrm{O}_{2}$ & $\mathrm{~S}_{\overline{\mathrm{v}}} \mathrm{O}_{2}$ & $\mathrm{C}_{\overline{\mathrm{v}} \mathrm{O}_{2}}$ & $\mathrm{CI}$ & HFI & $\mathrm{OFI}_{\mathrm{a}}$ & OFI $\bar{v}$ \\
\hline & & $h$ & $g /$ liter & torr & $\%$ & $\begin{array}{c}m l / \\
\text { liter }\end{array}$ & torr & $\%$ & $\begin{array}{c}\text { ml/ } \\
\text { liter }\end{array}$ & $\begin{array}{l}\text { liter } / \text { min } \\
\quad \text { per } m^{2}\end{array}$ & $\begin{array}{l}g / \text { liter } \\
\text { per } m^{2}\end{array}$ & $\begin{array}{c}m l / m i n \\
\text { per } m^{2}\end{array}$ & $\begin{array}{c}m l / m i n \\
\text { per } m^{2}\end{array}$ \\
\hline L. C. II & $7 / 27 / 72$ & 45 & 138 & 70 & 95.0 & 182 & 27.0 & 46.0 & 88 & 3.05 & 421 & 555 & 268 \\
\hline A. L. I & $9 / 6 / 72$ & 51 & 148 & 65 & 94.0 & 193 & 34.5 & 68.0 & 140 & 3.13 & 463 & 604 & 438 \\
\hline \multirow[t]{3}{*}{ J. N. } & $9 / 13 / 72$ & 2.3 & 149 & 62 & 93.0 & 193 & 31.0 & 6.3 .5 & 132 & 2.39 & 356 & 461 & 315 \\
\hline & $9 / 14 / 72$ & 45 & 1.37 & 67 & 93.0 & 177 & 36.0 & 71.0 & 135 & 2.53 & 347 & 448 & 342 \\
\hline & $9 / 15 / 72$ & 69 & 1.30 & 65 & 93.0 & 168 & 28.0 & 54.5 & 98 & 2.39 & 311 & 402 & 234 \\
\hline \multirow[t]{2}{*}{ L. H. II } & $9 / 19 / 72$ & 46 & 150 & 66 & 95.0 & 198 & - & - & 9.3 & 3.92 & 588 & 776 & 365 \\
\hline & $9 / 20 / 72$ & 66 & 143 & 65 & 95.0 & 189 & 37.0 & 77.0 & 153 & 4.29 & 613 & 811 & 656 \\
\hline \multirow[t]{2}{*}{ B. L. } & $9 / 25 / 72$ & 40 & 137 & 51 & 89.0 & 169 & 35.5 & 68.9 & 131 & 4.02 & 551 & 679 & 527 \\
\hline & $9 / 26 / 72$ & 63 & 136 & 59 & 94.0 & 178 & 33.5 & 69.5 & 131 & 3.09 & 420 & 550 & 405 \\
\hline W. D. I & $10 / 30 / 72$ & 94 & 145 & 67 & 94.0 & 189 & 35.0 & 74.0 & 149 & 3.82 & 554 & 722 & 569 \\
\hline D. J. & $10 / 30 / 72$ & 97 & 149 & 65 & 95.0 & 197 & 29.0 & 62.6 & 130 & 3.64 & 542 & 717 & 473 \\
\hline J. B. & $11 / 16 / 72$ & 70 & 141 & 67 & 96.0 & 188 & 32.0 & 63.7 & 125 & 2.84 & 400 & 534 & 355 \\
\hline \multirow[t]{2}{*}{ J. O. } & $12 / 11 / 72$ & 61 & 130 & 92 & 96.5 & 174 & 35.0 & 71.5 & 129 & 3.49 & 454 & 607 & 450 \\
\hline & $12 / 12 / 72$ & 85 & 117 & 63 & 93.8 & 153 & 33.5 & 66.7 & 108 & 3.39 & 397 & 519 & 366 \\
\hline \multirow[t]{3}{*}{ D. M. III } & $12 / 26 / 72$ & 40 & 137 & 39 & 84.8 & 161 & 18.0 & 29.6 & 56 & 2.76 & 378 & 444 & 155 \\
\hline & $12 / 27 / 72$ & 60 & 124 & 45 & 88.0 & 152 & 22.0 & 40.7 & 70 & 3.02 & 374 & 459 & 211 \\
\hline & $12 / 28 / 72$ & 83 & 121 & - & - & 150 & - & - & - & 2.86 & 346 & 429 & - \\
\hline \multirow{4}{*}{$\begin{array}{l}\text { H. M. III } \\
\text { C. G. IV }\end{array}$} & $12 / 28 / 72$ & 60 & 131 & 36 & 78.0 & 142 & 20.0 & 30.0 & 55 & 2.85 & 373 & 405 & 157 \\
\hline & $2 / 7 / 73$ & 6 & 156 & 147 & 83.0 & 180 & 30.0 & 55.0 & 119 & 2.54 & 396 & 457 & 302 \\
\hline & $2 / 8 / 73$ & 25 & 128 & 55 & 91.0 & 162 & 26.0 & 44.7 & 80 & 2.24 & 287 & 363 & 179 \\
\hline & $2 / 9 / 73$ & 51 & 107 & 101 & 98.0 & 146 & 25.0 & 46.8 & 70 & 1.97 & 211 & 288 & 138 \\
\hline \multirow[t]{2}{*}{ A. T. II } & $2 / 5 / 73$ & 62 & 1.31 & 171 & 99.4 & 181 & 31.0 & 63.3 & 115 & 3.37 & 441 & 610 & 388 \\
\hline & $2 / 6 / 73$ & 84 & 112 & 56 & 92.1 & 143 & 29.0 & 57.6 & 90 & 4.01 & 449 & 573 & 361 \\
\hline$n$ & & 23 & 23 & 22 & 22 & 23 & 21 & 21 & 22 & 23 & 23 & 23 & 22 \\
\hline Mean & & 57.7 & 135 & 71.5 & 92.3 & 172 & 29.9 & 58.3 & 109 & 3.11 & 420 & 540 & 348 \\
\hline SD & & 22.8 & 12.6 & 31.9 & 5.04 & 18.1 & 5.38 & 13.9 & 29.8 & 0.634 & 99.0 & 137 & 139 \\
\hline $\mathrm{SE}$ & & 4.76 & 2.64 & 6.81 & 1.08 & 3.78 & 1.17 & 3.03 & 6.36 & 0.132 & 20.6 & 28.5 & 29.6 \\
\hline
\end{tabular}

used to evaluate its relationship to oxygen flow (see Methods). The dependence of red cell 2,3-DPG on arterial $\mathrm{pH}, \mathrm{Hb} / \mathrm{HbO}_{2}$ (ta), or both was examined. There was a moderately strong and significant positive correlation of red cell 2,3-DPG content with arterial $\mathrm{pH}(r=0.46)$ and with $\mathrm{Hb} / \mathrm{HbO}_{2}$ (ta) $(r=0.55)$. The multiple correlation of 2,3-DPG with both arterial $\mathrm{pH}$ and $\mathrm{Hb} / \mathrm{HbO}_{2}$ (ta) was stronger and highly significant: $r=0.68, P<0.001$ (Table IV).

Alkalosis was a constant feature in these patients. Mean arterial $\mathrm{pH} 7.493 \pm 0.039$ (SD) was significantly higher than normal $(7.400 \pm 0.055)$. The $\mathrm{pH}$ range of $7.42-7.57$ in the 13 subjects indicates that the entire study population was shifted into the alkalotic range. $\mathrm{P}_{\mathrm{CO}_{2}}$ was low and base excess slightly elevated in arterial blood (Table I).

Relationship of $\mathrm{Ca}_{\mathrm{O}_{2}}$ and $\mathrm{CI}$ to blood $\mathrm{pH}$ and $\mathrm{Hb} / \mathrm{HbO}_{2}$ (ta). We next considered the possibility that $\mathrm{Ca}_{2}$ and $\mathrm{CI}$ exerted their influence on red cell, 2,3-DPG in one of the following ways. Firstly, changes in $\mathrm{Ca}_{\mathrm{O}_{2}}$ and $\mathrm{CI}$ might have influenced 2,3-DPG by influencing arterial $\mathrm{pH}$ or $\mathrm{Hb} / \mathrm{HbO}_{2}$ (ta). Alternatively, they may have influenced 2,3-DPG independently of an effect on $\mathrm{pH}$ or the ratio.
$\mathrm{Ca}_{2}$ was correlated significantly, although only moderately, with both arterial $\mathrm{pH}(r=-0.43)$ and $\mathrm{Hb} / \mathrm{HbO}_{2}$ (ta) $(r=-0.49)$. The multiple correlation of $\mathrm{Ca}_{\mathrm{O}_{2}}$ with both $\mathrm{pH}$ and $\mathrm{Hb} / \mathrm{HbO}_{2}$ (ta) was stronger $(r=0.60, P<0.01)$ (Table IV). CI was not correlated with arterial $\mathrm{pH}(r=0.03)$ and correlated weakly and not significantly with $\mathrm{Hb} / \mathrm{HbO}_{2}$ (ta) $(r=-0.38)$.

Red cell 2,3-DPG was found to be correlated independently with $\mathrm{Ca}_{\mathrm{C}_{2}}(r=-0.48)$ and $\mathrm{CI}(r=-0.34)$ when the effects of $\mathrm{pH}$ and $\mathrm{Hb} / \mathrm{HbO}_{2}$ (ta) were held constant with partial correlation statistics. The latter analysis is compatible with the possibility that factors independent of $\mathrm{pH}$ and $\mathrm{Hb} / \mathrm{HbO}_{2}$ (ta) may contribute to the relationship of $\mathrm{Ca}_{2}$ and $\mathrm{CI}$ with 2,3-DPG, although the intercorrelations of variables and the imperfect statistical techniques make it necessary to draw guarded inferences.

Oxygen binding to hemoglobin at in vivo conditions. To estimate the net change in $\mathrm{P}_{50}$ in vivo, $\mathrm{P}_{50}$ std was adjusted based on the presumptive additional effects of $\mathrm{P}_{\mathrm{CO}_{2}}, \mathrm{pH}$, and temperature (See Methods). $\mathrm{P}_{50}$ in vivo was correlated with red cell $2,3-\mathrm{DPG}(r=0.59)$, although this association was significantly less than that of $\mathrm{P}_{50}$ std with 2,3-DPG $(r=0.87)$ (Fig. 3B). $\mathrm{P}_{50}$ 
and Hemoglobin-Oxygen Affinity in Subjects with Myocardial Infarction

\begin{tabular}{|c|c|c|c|c|c|c|c|c|c|c|c|c|}
\hline$\dot{\mathrm{V}}_{\mathrm{O}_{2}}$ & $\begin{array}{l}\text { Propor- } \\
\text { tional } \\
\text { extrac- } \\
\text { tion }\end{array}$ & $\mathrm{pH}_{\mathrm{a}}$ & $\mathrm{pH}_{\mathrm{v}}$ & $\mathrm{Hb} / \mathrm{HbO}_{2 \mathrm{a}}$ & $\mathrm{Hb} / \mathrm{HbO}_{2 \mathrm{v}}$ & $\mathrm{Hb} / \mathrm{HbO}_{2}$ & $\mathrm{PaCO}_{2}$ & B.E.a & $\begin{array}{c}\text { Body } \\
\text { tempera- } \\
\text { ture }\end{array}$ & $\begin{array}{l}\text { Red cell } \\
2,3-\mathrm{DPG}\end{array}$ & $P_{50}$ std & $P_{50}$ i.v \\
\hline $\begin{array}{c}m l / \min \\
\text { per } m^{2}\end{array}$ & & & & & & ta & torr & & ${ }^{\circ} \mathrm{C}$ & $\begin{array}{c}\mu \mathrm{mol} / \\
\mathrm{g} \mathrm{Hb}\end{array}$ & torr & torr \\
\hline 287 & 0.52 & 7.42 & 7.39 & 0.0526 & 1.174 & 0.725 & 36 & -1.0 & 38.2 & 18.4 & 27.5 & 28.7 \\
\hline 166 & 0.27 & 7.47 & 7.45 & 0.0638 & 0.471 & 0.308 & 37 & +3.0 & 37.2 & 15.7 & 27.3 & 25.8 \\
\hline 146 & 0.32 & 7.44 & 7.41 & 0.0753 & 0.575 & 0.375 & 40 & +3.0 & 37.6 & 14.1 & 25.0 & 24.9 \\
\hline 106 & 0.24 & 7.49 & 7.46 & 0.0753 & 0.408 & 0.275 & 37 & +5.0 & 38.2 & 15.0 & 26.0 & 25.5 \\
\hline 168 & 0.42 & 7.50 & 7.46 & 0.0753 & 0.835 & 0.531 & 37 & +5.0 & 37.9 & 16.0 & 27.3 & 26.1 \\
\hline - & - & 7.48 & 7.43 & 0.0526 & 1.2 .37 & 0.763 & 38 & +5.0 & 38.0 & 13.1 & 24.5 & 24.1 \\
\hline 155 & 0.19 & 7.50 & 7.47 & 0.0526 & 0.299 & 0.200 & 38 & +6.0 & 37.0 & 13.6 & 24.5 & 22.3 \\
\hline 152 & 0.22 & 7.46 & 7.45 & 0.1240 & 0.451 & 0.320 & 35 & +2.0 & 38.3 & 14.2 & 26.0 & 26.3 \\
\hline 145 & 0.26 & 7.55 & 7.54 & 0.0638 & 0.439 & 0.289 & 28 & +3.0 & 38.0 & 15.1 & 26.3 & 23.8 \\
\hline 153 & 0.21 & 7.46 & 7.45 & 0.0638 & 0.351 & 0.236 & 32 & 0.0 & 37.3 & 13.6 & 23.5 & 22.4 \\
\hline 244 & 0.34 & 7.48 & 7.45 & 0.0526 & 0.597 & 0.379 & 34 & +2.0 & 38.0 & 14.1 & 23.8 & 23.2 \\
\hline 179 & 0.34 & 7.53 & 7.52 & 0.0417 & 0.570 & 0.359 & 34 & +6.0 & 38.1 & 19.6 & 27.3 & 25.6 \\
\hline 157 & 0.26 & 7.50 & 7.46 & 0.0363 & 0.399 & 0.254 & 36 & +5.0 & 38.7 & 15.2 & 24.0 & 24.0 \\
\hline 153 & 0.29 & 7.49 & 7.46 & 0.0661 & 0.499 & 0.326 & 32 & +1.5 & 38.0 & 17.4 & 26.5 & 25.5 \\
\hline 289 & 0.65 & 7.50 & 7.49 & 0.1790 & 2.378 & 1.498 & 33 & +2.5 & 37.4 & 18.8 & 29.0 & 26.7 \\
\hline 248 & 0.54 & 7.57 & 7.51 & 0.1360 & 1.457 & 0.929 & 30 & +6.0 & 37.2 & 19.8 & 30.0 & 25.6 \\
\hline- & - & 7.52 & - & 0.1240 & - & - & - & - & 38.0 & 19.6 & 28.0 & - \\
\hline 248 & 0.61 & 7.52 & 7.49 & 0.2820 & 2.333 & 1.513 & 30 & +2.0 & 38.0 & 21.7 & 29.5 & 27.5 \\
\hline 155 & 0.34 & 7.44 & - & 0.2050 & - & - & 34 & 0.0 & 37.9 & 16.1 & 28.0 & 28.2 \\
\hline 184 & 0.51 & 7.44 & 7.41 & 0.0989 & 1.237 & 0.782 & 40 & +3.0 & 38.4 & 16.7 & 27.4 & 28.6 \\
\hline 150 & 0.52 & 7.54 & 7.48 & 0.0204 & 1.137 & 0.690 & 31 & +4.0 & 38.2 & 19.2 & 28.5 & 26.4 \\
\hline 222 & 0.36 & 7.53 & 7.49 & 0.0060 & 0.580 & 0.350 & 39 & +9.0 & 37.3 & 17.8 & 27.5 & 24.9 \\
\hline 212 & 0.37 & 7.50 & 7.47 & 0.0858 & 0.736 & 0.476 & 35 & +4.0 & 37.3 & 17.7 & 28.0 & 25.8 \\
\hline 21 & 21 & 2.3 & 21 & 23 & 21 & 21 & 22 & 22 & 23 & 23 & 23 & 22 \\
\hline 187 & 0.371 & 7.492 & 7.461 & 0.0825 & 0.865 & 0.551 & 34.8 & +3.5 & 37.8 & 16.6 & 26.8 & 25.5 \\
\hline 50.8 & 0.136 & 0.0385 & 0.0365 & 0.0634 & 0.601 & 0.379 & 3.36 & - & 0.454 & 2.42 & 1.84 & 1.79 \\
\hline 11.1 & 0.0298 & 0.00803 & 0.00794 & 0.0132 & 0.131 & 0.0827 & 0.72 & - & 0.0946 & 0.504 & 0.384 & 0.382 \\
\hline
\end{tabular}

in vivo was also significantly correlated with $\mathrm{CI}$ $(r=-0.59)$ and $\mathrm{Ca}_{2}(r=0.46)$. Thus when the effects of $\mathrm{pH}, \mathrm{BE}$, and temperature were considered, in addition to that of red cell 2,3-DPG, $\mathrm{P}_{50}$ was more strongly associated with $\mathrm{CI}$ than $\mathrm{Ca}_{\mathrm{O}_{2}}$. When $\mathrm{P}_{50}$ in vivo was correlated with $\mathrm{CI}$, with the effect of temperature control, the correlation remained significant, although it was slightly reduced $(r=0.53) . \mathrm{P}_{50}$ in vivo was also correlated with $\mathrm{OFI}_{\mathrm{a}}(r=-0.68$, $P<0.001$ ) (Fig. 4), and with $\mathrm{CI}+\mathrm{Ca}_{\mathrm{O}_{2}}$ (multiple correlation) $(r=0.67, P<0.001)$ (Table IV).

Relationship of oxygen consumption to $O F I_{\mathrm{a}}$ and $P_{50}$. Oxygen consumption after myocardial infarction was independent of $\mathrm{Ca}_{\mathrm{O}_{2}}(r=-0.22)$, CI $(r=0.06)$, or $\mathrm{OFI}_{\mathrm{a}}(r=0.04)$ over a wide range of $\mathrm{OFI}_{\mathrm{a}}$ from 288 to $811 \mathrm{ml} / \mathrm{min}$ per $\mathrm{m}^{2}$ (Fig. 5). The maintenance of $\dot{\mathrm{V}}_{\mathrm{O}_{2}}$ was explained by a marked proportional increase in oxygen extraction as arterial oxygen flow rate fell. Indeed, the correlation of extraction with $\mathrm{OFI}_{\mathrm{a}}$ was highly significant (Fig. 6). Extraction increased $7.0 \%$ for every $100 \mathrm{ml} / \mathrm{min}$ per $\mathrm{m}^{2}$ decrement in $\mathrm{OFI}_{\mathrm{a}}$. In addition, as can be seen in the Table insert in Fig. 5, a stepwise increase in $P_{50}$ in vivo also occurred when the subjects were divided into three groups of equal numbers by decreasing $\mathrm{OFI}_{\mathrm{a}}$. Indeed, proportional extraction was strongly associated with $\mathrm{P}_{50}$ in vivo $(r=0.64, \quad P<0.01) \quad$ (Fig. 7). Hence, decreasing hemoglobin-oxygen affinity could account for about $40 \%\left(0.64^{2}\right)$ of the increment in proportional extraction, although the association does not establish causality.

We further quantified the possible contribution of reduced affinity to oxygen delivery by comparing the oxygen consumption that would have resulted if the position of the oxygen-hemoglobin dissociation curve present in subject $\mathrm{L}$. $\mathrm{H}$., with the highest $\mathrm{OFI}_{\mathrm{a}}$, was present in subject C. G., with the lowest $\mathrm{OFI}_{\mathrm{a}}$, and $\mathrm{Pa}_{\mathrm{O}_{2}}, \mathrm{PV}_{\mathrm{O}_{2}}$, and $\mathrm{CI}$ were unchanged. As shown in Table $\mathrm{V}, \dot{\mathrm{V}}_{\mathrm{O}_{2}}$ would have been severely reduced if proportional extraction had not increased to 0.52 . If the position of the oxygen-dissociated curve in vivo in subject C. G. was the same as L. H., $\dot{\mathrm{V}}_{\mathrm{O}_{2}}$ would have been $120 \mathrm{ml} / \mathrm{min}$ per $\mathrm{m}^{2}$ and proportional extraction 0.42 . A very similar result occurred if the $P_{50}$ in vivo of subject $\mathrm{C}$. G. was positioned at his in vivo conditions of $\mathrm{pH}$, temperature, and $\mathrm{P}_{\mathrm{CO}_{2}}$ and a normal red cell 2,3-DPG content. Two important inferences can be 
TABLE II

Association of Variables (Correlation Coefficients)

\begin{tabular}{|c|c|c|c|c|c|c|c|c|c|c|c|}
\hline & $\begin{array}{c}1 \\
\mathrm{Hb}\end{array}$ & $\begin{array}{c}2 \\
\mathrm{~S} \overline{\mathrm{v}} \mathrm{O}_{2}\end{array}$ & $\begin{array}{c}3 \\
\mathrm{CaO}_{2}\end{array}$ & $\begin{array}{c}4 \\
\text { CI }\end{array}$ & $\begin{array}{c}5 \\
\text { HFI }\end{array}$ & $\stackrel{6}{O F I_{a}}$ & $\begin{array}{c}7 \\
\mathrm{pH}_{\mathrm{a}}\end{array}$ & $\begin{array}{c}8 \\
\mathrm{Hb} / \mathrm{HbO}_{2} \\
\text { (ta) }\end{array}$ & $\stackrel{9}{2,3-\mathrm{DPG}}$ & $\begin{array}{c}10 \\
P_{50} \text { std }\end{array}$ & $\begin{array}{c}11 \\
\mathrm{P}_{50} \\
\text { in vivo }\end{array}$ \\
\hline A $\mathrm{Hb}$ & & -0.12 & +0.86 & +0.18 & +0.53 & +0.50 & -0.50 & -0.18 & -0.57 & -0.47 & -0.21 \\
\hline $\mathrm{B} \mathrm{S}_{\bar{v}} \mathrm{O}_{2}$ & & & +0.43 & +0.19 & +0.15 & +0.34 & +0.08 & -0.76 & -0.37 & -0.50 & -0.49 \\
\hline $\mathrm{C} \mathrm{CaO} 2$ & & & & +0.27 & +0.58 & +0.64 & -0.41 & -0.51 & -0.71 & -0.70 & -0.47 \\
\hline D CI & & & & & +0.92 & +0.91 & -0.03 & -0.34 & -0.43 & -0.51 & -0.59 \\
\hline E HFI & & & & & & +0.98 & -0.21 & -0.35 & -0.61 & -0.64 & -0.62 \\
\hline $\mathrm{F} \mathrm{OFI}$ & & & & & & & -0.18 & -0.47 & -0.65 & -0.71 & -0.69 \\
\hline $\mathrm{G} \mathrm{pH}_{\mathrm{a}}$ & & & & & & & & +0.15 & +0.46 & +0.37 & -0.29 \\
\hline $\mathrm{H} \mathrm{Hb} / \mathrm{HbO}_{2}(\mathrm{ta})$ & & & & & & & & & +0.65 & +0.67 & +0.54 \\
\hline I $2,3-\mathrm{DPG}$ & & & & & & & & & & +0.87 & +0.59 \\
\hline $\mathrm{J} \quad \mathrm{P}_{50}$ std & & & & & & & & & & & +0.73 \\
\hline
\end{tabular}

$0.41 \leq r \leq 0.52, P<0.05 ; 0.53 \leq r \leq 0.63, P<0.01 ; r \geq 0.64, P<0.001$.

The regression equations for each pair of variables in this table are given in Table III. The letter-number coordinates can be used to find the appropriate regression equation. For example, the regression of $\mathrm{CI}(\mathrm{Y})$ on $\mathrm{Hb}(\mathrm{X})$ can be found listed in Table III as coordinate $4, \mathrm{~A}$.

developed from this comparison. First, about $30 \%$ of the increase in proportional extraction $[(0.52$ $-0.42) \div(0.52-0.19)=0.10 \div 0.33]$ that occurred with decreased $\mathrm{OFI}_{\mathrm{a}}$ could be ascribed to a reduction in the binding of oxygen by hemoglobin; second, most of the increase in oxygen extraction at low oxygen flow appears to occur for other reasons.

$P_{50}$ std v's. $S \overline{\mathrm{v}}_{\mathrm{O}_{2}}$ as index of oxygen availability. To examine the usefulness of $P_{50}$ std or red cell 2,3-DPG as an index of systemic arterial oxygen delivery to

TABLE III

Linear Regression Equations for Variables Examined in 13 Subjects Studied Prospectively

\begin{tabular}{|c|c|c|c|}
\hline $\begin{array}{l}\text { Table II } \\
\text { coordinates }\end{array}$ & Regression & $\begin{array}{c}\text { Table II } \\
\text { coordinates }\end{array}$ & Regression \\
\hline $\begin{array}{l}\text { 2, A. } \\
\text { 3, A. } \\
\text { 4, A. } \\
\text { 5, A. } \\
\text { 6, A. } \\
\text { 7, A. } \\
\text { 8, A. } \\
\text { 9, A. } \\
\text { 10, A. } \\
\text { 11, A. } \\
\text { 3, B. } \\
\text { 4, B. } \\
\text { 5, B. } \\
\text { 6, B. } \\
\text { 7, B. } \\
\text { 8, B. } \\
\text { 9, B. } \\
\text { 10, B. } \\
\text { 11, B. } \\
\text { 4, C. } \\
\text { 5, C. } \\
\text { 6, C. } \\
\text { 7, C. } \\
\text { 8, C. } \\
\text { 9, C. } \\
\text { 10, C. } \\
\text { 11, C. } \\
\text { 5, D. }\end{array}$ & 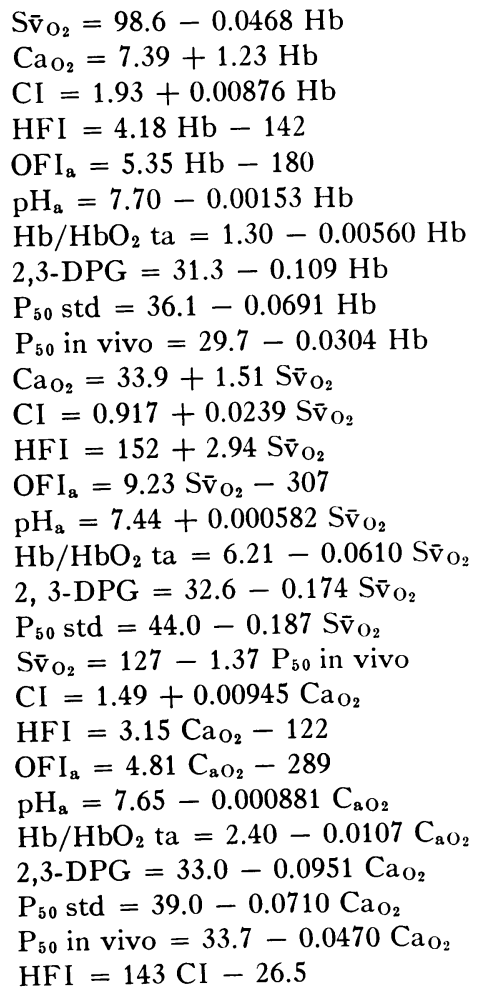 & $\begin{array}{l}\text { 6, D. } \\
\text { 7, D. } \\
\text { 8, D. } \\
\text { 9, D. } \\
\text { 10, D. } \\
\text { 11, D. } \\
\text { 6, E. } \\
\text { 7, E. } \\
\text { 8, E. } \\
\text { 9, E. } \\
\text { 10, E. } \\
11, \mathrm{E} . \\
7, \mathrm{~F} . \\
8, \mathrm{~F} . \\
9, \mathrm{~F} \\
\text { F, 10. } \\
11, \mathrm{~F} . \\
8, \mathrm{G} . \\
9, \mathrm{G} . \\
10, \mathrm{G} . \\
11, \mathrm{G} . \\
9, \mathrm{H} . \\
10, \mathrm{H} . \\
11, \mathrm{H} . \\
10, \mathrm{I} . \\
11, \mathrm{I} \\
11, \mathrm{~J} .\end{array}$ & 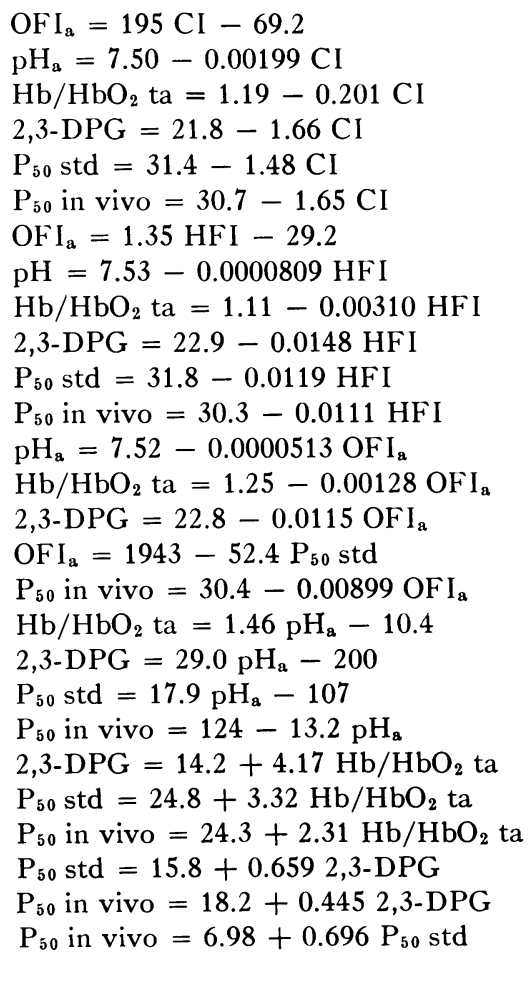 \\
\hline
\end{tabular}




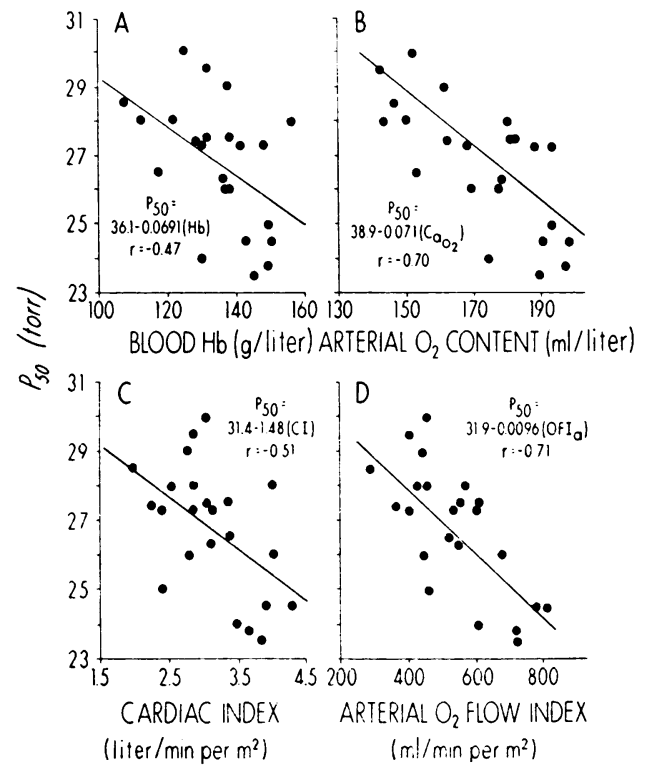

Figure 2 The regressions of $\mathrm{P}_{50}$ std on A. Hb, B. $\mathrm{Ca}_{2}, \mathrm{C}$. $\mathrm{CI}$, and $\mathrm{D} . \mathrm{OFI}_{\mathrm{a}}$ are shown.

tissue capillaries, we compared their relationship to $\mathrm{OFI}_{\mathrm{a}}$ with that of the relationship of $\mathrm{Sv}_{\mathrm{O}_{2}}$ to $\mathrm{OFI} \mathrm{I}_{\mathrm{a}}$. $\mathrm{S} \overline{\mathrm{V}}_{2}$ is a commonly used index of tissue oxygen uptake $(23,24)$. The correlations of $\mathrm{P}_{50}$ std $(r=-0.71$. $P<0.001)$ or red cell 2,3-DPG $(r=-0.65, P<0.001)$ with $\mathrm{OFI}_{\mathrm{a}}$ were very similar to that of the association of $\mathrm{S}_{\mathrm{O}_{2}}$ with $\mathrm{OFI}_{\mathrm{a}}(r=0.67, P<0.001)$. The correlation of $\mathrm{P}_{50}$ std with components of $\mathrm{OFI}_{\mathrm{a}}$, i.e., CI $(r=-0.51)$ and $\mathrm{Ca}_{\mathrm{O}_{2}}(r=-0.70)$ resembled that of $\mathrm{S} \overline{\mathrm{O}}_{\mathrm{O}_{2}}$ with $\mathrm{CI}(r=0.51)$ and $\mathrm{Ca}_{\mathrm{O}_{2}}(r=0.66)$. The regression of $\mathrm{OFI}_{\mathrm{a}}$ on $\mathrm{P}_{50}$ and $\mathrm{Sv}_{\mathrm{O}_{2}}$ is shown in Fig. 8 .

The correlation coefficients indicated that variations in $\mathrm{OFI}_{\mathrm{a}}$ explained on the average $50 \%$ of the variance

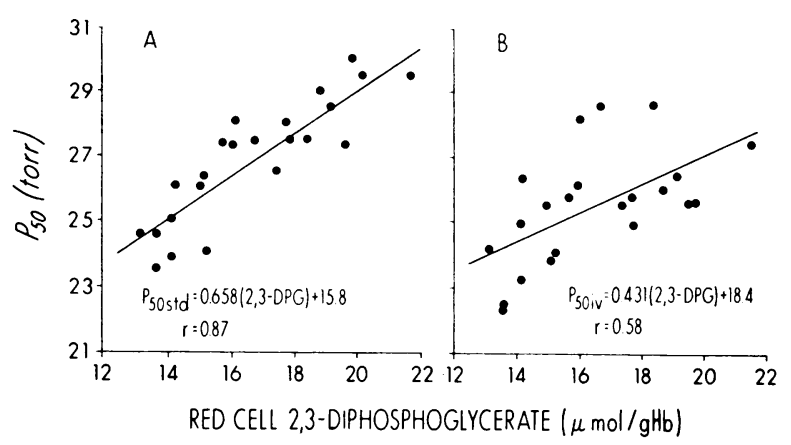

Figure 3 A. The regression of $P_{50}$ std on red cell 2,3-DPG is depicted. A highly significant association was present. $P_{50}$ std increased 1.0 torr for each increment of 2,3-DPG of 1.5 $\mu \mathrm{mol} / \mathrm{g} \mathrm{Hb}$. B. The regression of $\mathrm{P}_{50}$ in vivo on red cell 2,3DPG is shown. The increment in $P_{50}$ in vivo is significantly less than that of $P_{50}$ std with increased 2,3-DPG concentration. $\mathrm{P}_{50}$ in vivo increased 0.64 torr for each increment of 2.3-DPG of $1.5 \mu \mathrm{mol} / \mathrm{g} \mathrm{Hb}$.

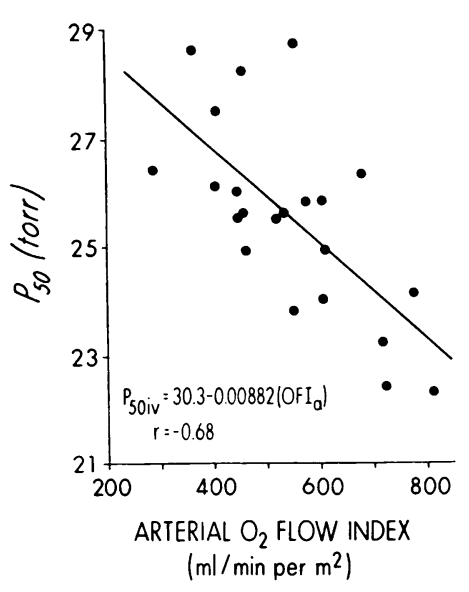

Figure 4 The regression of $\mathrm{P}_{50}$ in vivo on $\mathrm{OFI}_{2}$ is shown. The increment in $P_{50}$ in vivo is 0.88 torr per $100 \mathrm{ml} / \mathrm{min}$ per $\mathrm{m}^{2}$ reduction in $\mathrm{OFI}_{\mathrm{a}}$.

in $\mathrm{P}_{50}$ (i.e., $r^{2}$ ) and similarly it explained $45 \%$ of the variance in $\mathrm{S}_{\mathrm{O}_{2}}$. $\quad \mathrm{P}_{\mathrm{O}_{2}}$ was highly correlated with $\mathrm{S} \overline{\mathrm{V}}_{\mathrm{O}_{2}}(r=+0.98)$ over this range of $\mathrm{P} \overline{\mathrm{v}}_{\mathrm{O}_{2}}$, which is in the central, nearly linear, portion of the oxygenhemoglobin dissociation. Hence, the results were similar with either $\mathrm{P} \overline{\mathrm{v}}_{\mathrm{O}_{2}}$ or $\mathrm{S} \overline{\mathrm{v}}_{\mathrm{O}_{2}}$ for analysis.

The multiple correlation of $\mathrm{Sv}_{\mathrm{O}_{2}}$ with $\mathrm{Ca}_{\mathrm{O}_{2}}, \mathrm{CI}$, and $\mathrm{P}_{50}$ in vivo was very strong $(r=0.77, P<0.001)$. (Table IV). This suggests that on the average about $60 \%$ of the variance $\left(0.77^{2}\right)$ in $\mathrm{Sv}_{\mathrm{O}_{2}}$ could be explained by changes in $\mathrm{OFI}_{\mathrm{a}}$ plus changes in affinity.

Relationship of $P_{50}$ to clinical status. Reduction in $\mathrm{Ca}_{\mathrm{O}_{2}}$ and $\mathrm{CI}$ should be correlated with a severity of

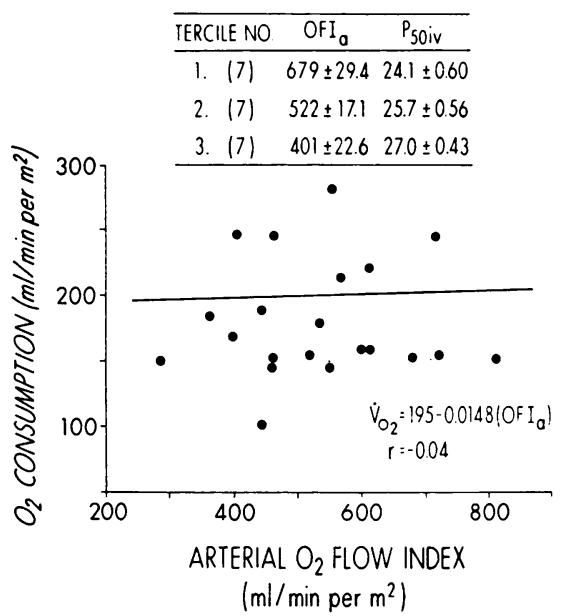

FIGLRE 5 Oxygen consumption is shown in relationship to $\mathrm{OFI}_{\mathrm{a}}$. The slope of the regression of oxygen consumption on $\mathrm{OFI}_{\mathrm{a}}$ is zero. The inserted table shows the mean $\pm \mathrm{SD}$ of the $\mathrm{P}_{50}$ in vivo for three ranges of $\mathrm{OFI}_{\mathrm{a}}$ : normal, moderately. reduced, and markedly reduced. A stepwise increase in $P_{50}$ in vivo is seen. The mean differences in $\mathrm{P}_{50}$ are highly significant when tested by analysis of variance $(P<0.01)$. 
TABLE IV

Multiple Correlation Coefficients and Linear Multiple Regression Equations

\begin{tabular}{lcc}
\hline \multicolumn{1}{c}{ Multiple regression equation } & $\begin{array}{c}\text { Correlation } \\
\text { coefficient }\end{array}$ & $P$ \\
\hline $2,3-\mathrm{DPG}=23.3 \mathrm{pH}_{\mathrm{a}}+3.82 \mathrm{Hb} / \mathrm{HbO}_{2} \mathrm{ta}-160$ & $r=0.74$ & 0.001 \\
$\mathrm{P}_{50}$ std $=40.5-0.0615 \mathrm{Ca}_{O_{2}}-1.00 \mathrm{CI}$ & $r=0.77$ & 0.001 \\
$\mathrm{P}_{50}$ in vivo $=35.8-0.0339 \mathrm{Ca}_{2}-1.41 \mathrm{CI}$ & $r=0.68$ & 0.001 \\
$\mathrm{Ca}_{\mathrm{O}_{2}}=1,324-152 \mathrm{pH}_{\mathrm{a}}-22.5 \mathrm{Hb} / \mathrm{HbO}_{2} \mathrm{ta}$ & $r=0.60$ & 0.01 \\
$\mathrm{~S}_{\mathrm{v}_{2}}=70.5+0.312 \mathrm{Ca}_{2}-3.10 \mathrm{P}_{50}$ in vivo $+4.39 \mathrm{CI}$ & $r=0.79$ & 0.001
\end{tabular}

myocardial infarction, as judged by clinical criteria. Indeed, this was corroborated in this series of 13 subjects, since the plasma creatine phosphokinase activity was inversely correlated with $\mathrm{CI}$ and $\mathrm{Ca}_{\mathrm{O}_{2}}$, measured on the day after the serum enzyme measurement (data not shown).

We examined the possibility that $\mathrm{P}_{50}$ std might also reflect the severity of the infarction as judged by clinical criteria. Oxygen flow, binding, and utilization as well as blood $\mathrm{pH}$ and $\mathrm{Hb} / \mathrm{HbO}_{2}$ (ta) were calculated in the 49 patients in the MIRU who were studied retrospectively (Table VI). Mean arterial $\mathrm{pH}$ was elevated in each class of patients. However, the proportion of subjects with arterial $\mathrm{pH}$ below 7.36 increased with increasing severity of infarction (class I + II $=1 / 31$ or $3 \%$, class III $+\mathrm{IV}=4 / 18$ or $22 \%$ ). $\mathrm{Hb} / \mathrm{HbO}_{2}$ (ta) increased and $\mathrm{S} \overline{\mathrm{O}}_{\mathrm{O}_{2}}$ decreased significantly with severity of clinical state. Although $\mathrm{S}_{\mathrm{O}_{2}}$ was correlated with $\mathrm{Ca}_{2}(r=0.35, P<0.02)$ and $\mathrm{CI}$

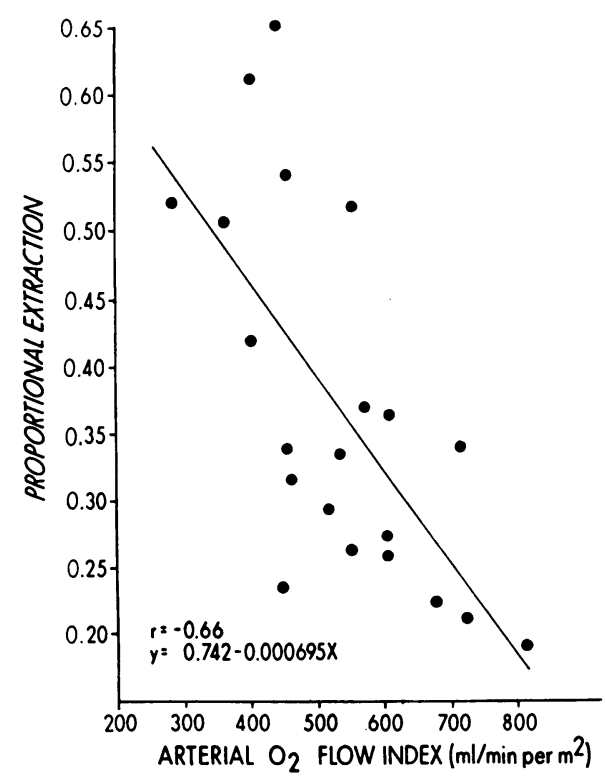

Figure 6 The relationship of proportional extraction of oxygen from arterial blood to oxygen flow rate index is shown.
( $r=0.51, P<0.001)$, it was most strongly associated with $\mathrm{OFI}_{\mathrm{a}}(r=0.60, P<0.001)$.

$\mathrm{P}_{50}$ std of 17 normal subjects measured in our laboratory was $26.6 \pm 0.75$ (SD) torr. Mean initial $P_{50}$ std was similar to normal in class I patients, whereas it was significantly elevated in class II patients and highly significantly elevated in class III patients. In class IV subjects, $\mathrm{P}_{50}$ std was not increased significantly. $\mathrm{P}_{50}$ std was significantly $(P<0.05)$ but weakly correlated with $\mathrm{CI}(r=-0.23), \mathrm{Ca}_{\mathrm{O}_{2}}(r=-0.31)$ and $\mathrm{OFI}_{\mathrm{a}}(r=-0.36)$ in the 49 subjects studied on admission to MIRU. These correlations were stronger if class IV subjects were omitted. Moreover, the correlations are a function of time-dependent changes in red cell 2,3-DPG that may not have occurred at the time of the initial study.

$\mathrm{P}_{50}$ in vivo was significantly elevated in subjects in class II and III. Despite a stepwise and marked decrease in $\mathrm{OFI}_{\mathrm{a}}$ as severity of infarction increased, 
TABLE V

The Influence of $P_{50}$ in :ivo on Proportional Extraction of Oxygen

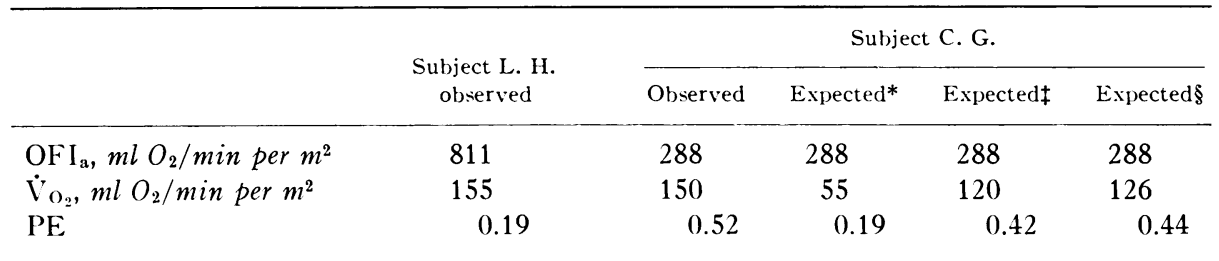

$\mathrm{PE}=$ proportional extraction of oxygen $=\mathrm{V}_{\mathrm{O}_{2}} / \mathrm{OFI}_{\mathrm{a}}$.

* The $\dot{V}_{\mathrm{O}_{2}}$ expected if proportional extraction did not increase with decreasing $\mathrm{OFI}_{\mathrm{a}}$.

$\dagger$ The $\dot{V}_{\mathrm{O}_{2}}$ expected if the $P_{50}$ in vivo in subject $C$. G. was the same as in subject $L$. H.

$\S$ The $\dot{V}_{\mathrm{O}_{2}}$ expected if C. G.'s red cell 2,3-DPG was 14.0 (normal mean) rather than 19.2 $\mu \mathrm{mol} / \mathrm{g} \mathrm{Hb}$ (observed value) and $\mathrm{P}_{50}$ in vivo was reduced based on the relationship of $\mathrm{P}_{50}$ to 2,3-DPG (Fig. 3B).

mean oxygen consumption $\left(\dot{\mathrm{V}}_{\mathrm{O}_{2}}\right)$ increased slightly in class II and III subjects as compared to class I subjects. Like $\mathrm{P}_{50}$ in vivo, $\dot{\mathrm{V}}_{\mathrm{O}_{2}}$ did not increase in class IV patients; rather, the latter two variables were not different from class I subjects.

The possible quantitative role of oxygen-hemoglobin affinity in maintaining tissue oxygen consumption was examined (Fig. 9). Mean $\mathrm{OFI}_{\mathrm{a}}$ decreased linearly from clinical class I to class IV (Fig. 9A), but mean $\mathrm{P}_{50}$ in vivo, $\dot{\mathrm{V}}_{\mathrm{O}_{2}}$, and proportional extraction of oxygen were correlated with mean $\mathrm{OFI}_{\mathrm{a}}$ only in classes I through III. This relationship was broken when class IV subjects were examined (Fig. 9). The lines in Fig. 9 do not represent the regression for the 49 individual observations. They are the best fit lines connecting the means of subjects in classes I through III. If $\dot{\mathrm{V}}_{\mathrm{O}_{2}}$ for class II, III, and IV subjects was recalculated at the $\mathrm{P}_{50}$ in vivo of class I subject, $\dot{\mathrm{V}}_{\mathrm{O}_{2}}$ and proportional extraction would have been reduced as shown by the open squares in Figs. 9C and D. Even so, proportional extraction increased, and $\dot{\mathrm{V}}_{\mathrm{O}_{2}}$ would have been $89 \%$ (class II), $75 \%$ (class III), and $94 \%$ (class IV) of the observed values in the absence of an increase in $\mathrm{P}_{50}$ in vivo. We conjecture, from these data, that class IV subjects, already extracting oxygen maximally, are compromised further by an inability to decrease oxygen binding to hemoglobin and to thereby satisfy the

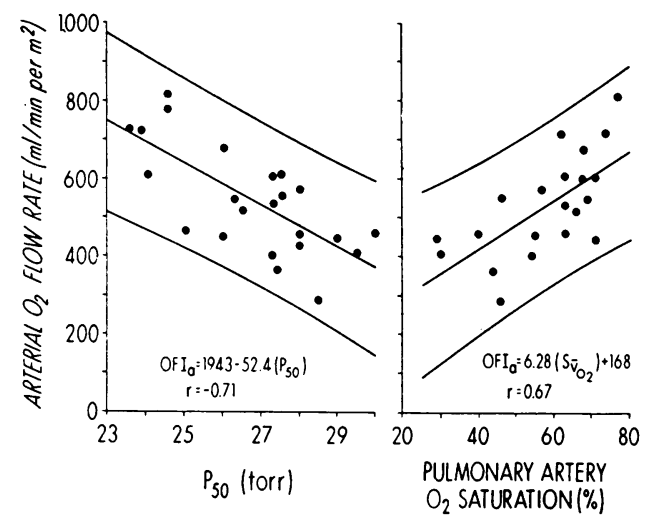

FIGURE 8 The relationship of $\mathrm{OFI}_{\mathrm{a}}$ to either $\mathrm{P}_{50}$ std or $\mathrm{S}_{\overline{\mathrm{V}}} \mathrm{O}_{2}$ is shown.

TABLE VI

Oxygen Flow, Binding and Utilization during Initial $24 \mathrm{~h}$ after Myocardial Infarction in 49 Subjects

\begin{tabular}{lcccc}
\hline & \multicolumn{4}{c}{ Class } \\
\cline { 2 - 5 } & \multicolumn{1}{c}{ I } & II & III & IV \\
& $n=14$ & $n=17$ & $n=13$ & $n=5$ \\
\hline $\mathrm{pH}_{2}$ & $7.429 \pm 0.013$ & $7.471 \pm 0.014$ & $7.432 \pm 0.023$ & $7.428 \pm 0.043$ \\
$\mathrm{Hb} \mathrm{HbO}_{2}$ (ta) & $0.29 \pm 0.022$ & $0.40 \pm 0.042$ & $0.62 \pm 0.12$ & $0.73 \pm 0.17$ \\
$\mathrm{P}_{50}$ std, torr & $26.9 \pm 0.75$ & $28.7 \pm 0.91$ & $31.2 \pm 0.98$ & $27.1 \pm 1.3$ \\
$\mathrm{P}_{50}$ i.v., torr & $26.0 \pm 0.81$ & $28.0 \pm 1.0$ & $31.4 \pm 1.1$ & $26.8 \pm 1.3$ \\
$\mathrm{~S}_{\mathrm{O}_{2}}, \%$ \% & $70.6 \pm 1.4$ & $63.9 \pm 2.7$ & $55.5 \pm 4.1$ & $48.6 \pm 5.8$ \\
$\mathrm{OFI}_{\mathrm{a}} \mathrm{ml} /$ min per $m^{2}$ & $587 \pm 35$ & $520 \pm 40$ & $434 \pm 31$ & $325 \pm 64$ \\
$\dot{\mathrm{V}}_{\mathrm{O}_{2}}, \mathrm{ml} /$ min per $m^{2}$ & $139 \pm 8.3$ & $149 \pm 12$ & $179 \pm 16$ & $148 \pm 15$ \\
\hline
\end{tabular}

Mean $\pm S E$. 

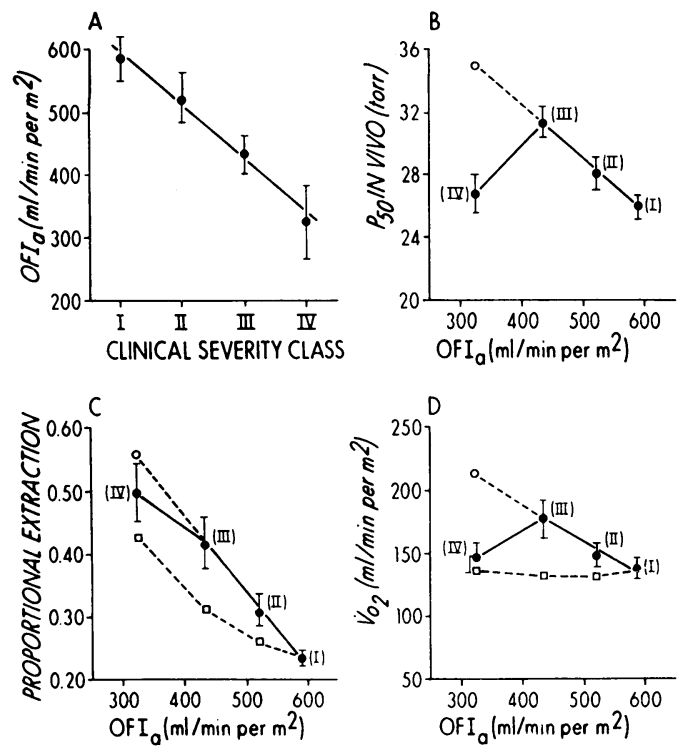

Figure 9 A. The arterial oxygen flow rate index (mean \pm SE) as a function of clinical class. $B$. The $P_{50}$ in vivo (mean $\pm S E$ ) of each class of patients plotted against the mean $\mathrm{OFI}_{\mathrm{a}}$ for each class. The open circle indicates the $P_{50}$ in vivo expected in class IV subjects bas edon a linear extrapolation of the regression line. C. The proportional extraction of oxygen (mean $\pm \mathrm{SE}$ ) for each class of subjects plotted against their mean $\mathrm{OFI}_{\mathrm{a}}$. The open circle represents the expected extraction based on the extrapolation of the linear regression. The open squares indicate the mean extraction if $\dot{\mathrm{V}}_{\mathrm{O}_{2}}$ in class II, III, and IV subjects was calculated based on the $P_{50}$ in vivo observed in class I subjects. D. Oxygen consumption (mean \pm $\mathrm{SE}$ ) for each class of subjects plotted against the mean $\mathrm{OFI}_{\mathrm{a}}$ for each class. The open circle indicates the $\dot{V}_{\mathrm{O}_{2}}$ expected in class IV subjects based on the linear extrapolation of the regression line. The open squares indicate the expected mean $\dot{\mathrm{V}}_{\mathrm{O}_{2}}$ if $\mathrm{P}_{30}$ in vivo of class II, III, and IV subjects was that of class I subjects.

oxygen consumption projected for this group of subjects.

\section{DISCUSSION}

We have studied the variables that determine arterial oxygen flow, individually and in combination, to determine the magnitude of their changes and the effect of such changes on oxygen binding by hemoglobin, and oxygen utilization, in patients with myocardial infarction. The association of $\mathrm{P}_{50}$ std with hemoglobin concentration, CI, and hemoglobin flow rate in subjects with myocardial infarction studied at least $24 \mathrm{~h}$ after onset of symptoms confirmed results reported previously by Woodson and coworkers in subjects with chronic heart failure (9). In fact, the quantitative relationships of $\mathrm{P}_{50}$ std with blood hemoglobin, CI, and HFI were virtually identical in our study to those found by Woodson et al.
The dependence of $\mathrm{P}_{50}$ std upon hemoglobin concentration in the present study was less than that observed in anemic subjects in our own (25) and other laboratories $(26,27)$. This is likely due to the fact the blood $\mathrm{pH}$ and $\mathrm{Hb} / \mathrm{HbO}_{2}$ ratio were dependent on other variables, as well as hemoglobin concentrations in these subjects. $P_{50}$ std (i.e., red cell 2,3-DPG content) was most strongly associated with $\mathrm{Ca}_{\mathrm{O}_{2}}$ and $\mathrm{OFI}_{\mathrm{a}}$ and the dependence of $\mathrm{P}_{50}$ on $\mathrm{OFI}_{\mathrm{a}}$ was significantly greater than on $\mathrm{HFI}$, indicating the additional importance of oxygen saturation of hemoglobin. HFI explained, on the average, $35 \%$ of the variation in $\mathrm{P}_{50}$, whereas OFI explained $50 \%$ of the variation in $\mathrm{P}_{50}$.

In contrast to the reported results of Kostuk and colleagues (9), the changes observed in $\mathrm{P}_{50}$ std in our patients were nearly entirely dependent on changes in red cell 2,3-DPG content. The precise cause of the alterations in red cell 2,3-DPG with reduced arterial oxygen flow has been partially elucidated. Alkalosis in arterial blood was a constant feature in our subjects and correlated with $\mathrm{OFI}_{\mathrm{a}}$ and 2,3-DPG. Descriptive studies in man $(28,29)$ and animals $(30)$ have indicated that an initial respiratory alkalosis in response to altitude hypoxia precedes a later elevation in red cell 2,3-DPG. A strong association of blood $\mathrm{pH}$ and red cell 2,3-DPG has also been shown in analytical studies of patients with changes in acid-base balance (25, 31-36). In addition, experimental studies in man have provided evidence of the causal dependence of red cell 2,3-DPG content on blood $\mathrm{pH}(22,25,32)$. The possible role of elevated $\mathrm{pH}$ in modulating rates of enzyme activity leading to the heightened cellular 2,3-DPG levels have been discussed in detail previously $(2,30,37)$. Hence, blood $\mathrm{pH}$ could have been a causal intermediary between reduced $\mathrm{OFI}_{\mathrm{a}}$ and elevated 2,3DPG. The association of $\mathrm{pH}$ with red cell 2,3-DPG in these studies was lower than correlations previously reported by others in various clinical disorders. The effect of $\mathrm{pH}$ on red cell 2,3-DPG is time-dependent and hence, the correlation of a single $\mathrm{pH}$ value with 2,3DPG is at best an approximation, especially during an acutely changing clinical disorder. From the considerable evidence relating red cell 2,3-DPG to blood $\mathrm{pH}$, we infer that the elevated blood $\mathrm{pH}$ in our subjects contributed to the elevated red cell 2,3-DPG.

When plasma alkalosis is the central stimulus to increased 2,3-DPG elevation, little if any net reduction in oxygen binding by hemoglobin occurs in vivo, since the two opposing effects on red cell $\mathrm{pH}$ cancel each other $(22,25)$. In our studies, although a significant regression of $P_{50}$ in vivo on red cell 2,3-DPG was present, mean $P_{50}$ in vivo for all the study subjects (25.5 torr) was slightly below normal for our laboratory (26.6 torr), despite an increase in mean 2,3-DPG of about $3 \mu \mathrm{mol} / \mathrm{g} \mathrm{Hb}$, due to alkalosis. The significant 
regression of $\mathrm{P}_{50}$ in vivo on red cell 2,3-DPG was related to the reduced $\mathrm{P}_{50}$ in vivo in alkalotic subjects with as yet normal 2,3-DPG concentrations. Hence, temporal factors may have accounted for the residual regression, the surmise being that in time $2,3-\mathrm{DPG}$ accumulation in alkalotic subjects would restore $P_{50}$ in vivo to an approximately normal value (25). Also, the residual regression of $\mathrm{P}_{50}$ in vivo may be explicable by the role of the $\mathrm{Hb} / \mathrm{HbO}_{2}$ ratio as a mediator of red cell 2,3-DPG content after myocardial infarction. It has been suggested that the proportion of deoxyhemoglobin in the red cell is an important determinant of red cell 2,3-DPG content $(20,38)$.

In the present studies $\mathrm{Hb} / \mathrm{HbO}_{2}$ (ta) ratio was significantly correlated with $\mathrm{OFI}_{\mathrm{a}}$ and 2,3-DPG. Timeaveraging allowed us to approximate the $\mathrm{Hb} / \mathrm{HbO}_{2}$ ratio during transit through venous as well as arterial circulation, since the effect of the ratio on red cell $\mathrm{pH}$ and the proportion of 2,3-DPG bound to $\mathrm{Hb}$ would be most consequential in venous blood. Although the importance of the proportion of deoxyhemoglobin as a determinant of red cell 2,3-DPG has been noted $(20,38)$, the mechanism of the effect of the $\mathrm{Hb} / \mathrm{HbO}_{2}$ has not been defined with certainty. Since deoxyhemoglobin is a weaker acid than oxyhemoglobin, the concentration of hydrogen ions in the cell is reduced by desaturation of hemoglobin. Red cell $\mathrm{pH}$ increases about 0.025 units as oxygen saturation of hemoglobin falls from 100 to $50 \%$ (39). If $\mathrm{Hb} / \mathrm{HbO}_{2}$ ratio operate: to increase 2,3-DPG by an elevation of red cell $\mathrm{pH}$, this effect is not considered in the $\mathrm{P}_{50}$ in vivo equation. which makes a pH correction based on the effects of plasma $\mathrm{pH}$ changes only. This additional correction would reduce the regression of $\mathrm{P}_{50}$ in vivo on 2,3-DPG and reduce even further the contribution of decreased affinity to maintenance of oxygen consumption. An additional effect of deoxygenation relates to the role of 2,3-DPG as a modulator of enzyme reactions in the Embden-Meyerhof and Rapoport-Luebering pathways $(2,37)$. The acceleration of enzymes in these pathways as a result of binding of free 2,3-DPG to deoxygenated hemoglobin has been suggested as an additional contribution to an elevated red cell 2,3-DPG content. Such an effect could decrease affinity without the cost of intracellular alkalosis, although the role of such an effect is speculative.

A proportional increase in the extraction of oxygen resulted in a similar oxygen consumption in the 13 subjects studied prospectively, despite a nearly threefold variation in $\mathrm{OFI}_{\mathrm{a}}$. The mechanism for the increased extraction could not be fully explained. About one-third of the increase in oxygen removal with decreased $\mathrm{OFI}_{\mathrm{a}}$ may have been related to the decrease in hemoglobin-oxygen affinity. This partial effect of affinity change was also evident in the larger group of subjects studied retrospectively, in whom about one-quarter to one-half of the increase in proportional extraction could be explained by affinity changes. However, $\dot{V}_{\mathrm{O}_{2}}$ was maintained at "normal" levels, due to a heightened extraction from a reduced arterial oxygen flow even in the absence of an affinity change. The possible clinical importance of the maintenance of $\dot{\mathrm{V}}_{\mathrm{O}_{2}}$ with decreased affinity, as seen in class III subjects, as contrasted to a lower $\dot{\mathrm{V}}_{\mathrm{O}_{2}}$ and failure to decrease affinity in class IV subjects, cannot be assessed from our data.

The failure to find an increased mean $P_{j 0}$ std (i.e. red cell 2,3-DPG) in the clinical class IV subjects could be related to three factors: first, the small number of observations in that group; second, the presence of nonalkalemic subjects; and third, the time required for red cell 2,3-DPG accumulation after alkalosis or arterial blood desaturation (22). Three of the five subjects in class IV were first studied within $26 \mathrm{~h}$ of onset of symptoms. We anticipated the analyses of these data would be complicated by important temporal considerations. Even so, it was of interest to examine the usefulness of $P_{50}$ std as an index of severity of infarction by correlating it with class early in the clinical evaluation.

$P_{50}$ std or red cell 2,3-DPG proved to be as good an index of reduced blood flow or oxygen flow rate as $S \bar{v}_{\mathrm{O}_{2}}$ in the 13 subjects studied prospectively. However, these subjects were for the most part in class I or class II (10 of 13), all were alkalotic, and the studies were done, in almost all cases, more than $24 \mathrm{~h}$ after onset of symptoms. $\mathrm{S}_{\mathrm{O}_{2}}$ appears to be the better of the two variables as an index of reduced $\mathrm{OFI}_{\mathrm{a}}$, since its correlation with $\mathrm{OFI}_{\mathrm{a}}$ was not influenced by temporal considerations and did not appear to be affected by the presence or absence of affinity changes (see Table IV). Neither is a highly accurate predictive index of oxygen flow in an individual subject, since the $95 \%$ tolerance limits for $\mathrm{OFI}_{\mathrm{a}}$ for a given $\mathrm{S}_{\mathrm{O}_{2}}$ or $\mathrm{P}_{50}$ std are too broad to be used precisely. Nevertheless, serial measurements of $\mathrm{S}_{\mathrm{O}_{2}}$ may be of value, as has been previously suggested $(26,27)$.

It has been suggested that red cell 2,3-DPG or its, counterpart $\mathrm{P}_{50}$, measured at $\mathrm{pH} 7.40$ and $\mathrm{P}_{\mathrm{CO}_{2}}$ of 40 torr are biochemical indicators of tissue oxygenation (27). The implication is that red cell 2,3-DPG increases as oxygen supply is compromised. This is not necessarily true if alkalosis or marked desaturation is not an accompanying event and if time-dependent changes have not occurred. Alkalosis appears to be a frequent response to reduced arterial oxygen flow rate, whether the latter occurs due to anemia, hypoxia, or low flow. However, in the presence of acidosis, even if $\mathrm{Hb} / \mathrm{HbO}_{2}$ is increased, changes in red cell 2,3-DPG are blunted. This may explain the failure of $2,3-\mathrm{DPG}$ to increase 
in certain subjects with hypoxic chronic pulmonary disease (40) and anemic subjects with severe azotemia (25), each of whom are limited in their ability to develop alkalosis in response to reduced $\mathrm{OFI}_{a}$

The initial hours of myocardial infarction in many subjects appear to be marked by respiratory alkalosis and therefore increased binding of oxygen by hemoglobin. This may impair oxygen delivery before adaptive red cell changes and contribute to the high rate of early complications. Acidosis, on the other hand, impairs the ability of the red cell to generate $2,3-\mathrm{DPG}$ and may compromise a critical aspect of the later adaptation to falling arterial oxygen flow. Further examination of the role of acid-base changes after myocardial infarction should be made to determine what constitutes an optimal metabolic response and whether therapeutic modification of a deleterious response can be made.

\section{ACKNOWLEDGMENTS}

The authors are indebted to the clinical professional staff of the Rochester Myocardial Infarction Research Unit (Dr. Morrison Hodges, supervisor) for permission to include the physiological data obtained during study of their patients: and to the MIRU data-processing section (W. Bromley Clark, Ph.D., supervisor) for assistance with data retrieval. The authors are also indebted to Stella Mickys for her help in preparation of the manuscript.

This work was supported by a contract with the U. S. Army Research and Development Command No. DADA 17-73-C-3135 and U. S. Public Health Service research grants CA 12790 , HE 06241, and training grant HL 05500, a grantin-aid from the Genesee Valley Heart Association, MIRU contract PH-43-68-1331 from the U. S. Public Health Service, and by the Atomic Energy Project at the University of Rochester. It has been assigned publication number UR3490-506.

\section{REFERENCES}

1. Finch, C. A., and C. Lenfant. 1972. Oxygen transport in man. N. Engl. J. Med. 286: 407-415.

2. Rørth, M. 1972. Hemoglobin interactions and red cell metabolism. Ser. Haematol. 5: 1-104.

3. Torrance, J., P. Jacobs, A. Restrepo, J. Eschbach, C. Lenfant, and C. A. Finch. 1970. Intraerythrocytic adaptation to anemia. N. Engl. J. Med. 283: 165-169.

4. Rørth, M., and P. Astrup, ed. 1972. Oxygen affinity of hemoglobin and red cell acid base status. Munksgaard, A/S Copenhagen.

5. Lenfant, C., J. Torrance, E. English, C. A. Finch, C. Reynafarje, J. Ramos, and J. Faura. 1968. Effect of altitude on oxygen binding by hemoglobin and on organic phosphate levels. J. Clin. Invest. 47: 2652-2656.

6. Lenfant, C., J. D. Torrance, and C. Reynafarje. 1971. Shift of the $\mathrm{O}_{2}-\mathrm{Hb}$ dissociation curve at altitude: mechanism and effect. J. A ppl. Physiol. 30: 625-631

7. Woodson, R. D., J. D. Torrance, S. D. Shappell, and C. Lenfant. 1970. The effect of cardiac disease on hemoglobin-oxygen binding. J. Clin. Invest. 49: 1349-1356.

8. Metcalfe, J., D. S. Dhindsa, M. J. Edwards, and A. Mourdjinis. 1969. Decreased affinity of blood for oxygen in patients with low-output heart failure. Circ. Res. 25: $47-51$

9. Kostuk, W. J., K. Suwa, E. F. Bernstein, and B. E. Sobel. 1973. Altered hemoglobin oxygen affinity in patients with acute myocardial infarction. Am. J. Cardiol. 31:295-299.

10. Interiano, B., R. W. Hyde, M. Hodges, and P. N. Yu. 1973. Interrelation between alterations in pulmonary mechanics and hemodynamics in acute myocardial infarction. J. Clin. Invest. 52: 1994-2006.

11. Severinghaus, J. W. 1966. Blood gas calculator. J. Appl. Physiol. 21: 1108-1116.

12. Van Slyke, D. D., and J. M. Neill. 1924. Determination of gases in blood and other solutions by vacuum extraction and manometric measurement. J. Biol. Chem. 61: 523-573.

13. Rose, Z. B., and J. Liebowitz. 1970. Direct determination of 2,3-diphosphoglycerate. Anal. Biochem. 35: 177-180.

14. Goldstein, A. Biostatistics. 1964. The Macmillan Company, New York. 1st edition.

15. Snedecor, G. W. 1956. Statistical methods. Iowa State University Press, Ames, Iowa. 5th Edition.

16. Ezekiel, M., and K. A. Fox. 1959. Methods of correlation and regression analysis. John Wiley \& Sons, Inc., New York. 3rd edition.

17. Murphy, J. R. 1960. Erythrocyte metabolism. II. Glucose metabolism and pathways. J. Lab. Clin. Med. 55: 286302.

18. Asakura, T., Y. Sato, S. Minakami, and H. Yoshikawa. 1966. $\mathrm{pH}$ dependency of 2,3-diphosphoglycerate content in red blood cells. Clin. Chim. Acta. 14:840-841.

19. Duhm, J. 1971. Effects of 2,3-diphosphoglycerate and other organic phosphate compounds on oxygen affinity and intracellular $\mathrm{pH}$ of human erythrocytes. Pfü̈gers Arch. Eur. J. Physiol. 326: 341-356.

20. Asakura, T., Y. Sato, S. Minakami, and H. Yoshikawa. 1966. Effect of deoxygenation of intracellular hemoglobin on red cell glycolysis. J. Biochem. 59: 524-526.

21. Astrup, P., K. Engel, J. N. Severinghaus, and E. Munson. 1965. The influence of temperature and $\mathrm{pH}$ on the dissociation curve of oxyhemoglobin of human blood. Scand. Clin. Lab. Invest. 17: 515-523.

22. Bellingham, A. J., J. C. Detter, and C. Lenfant. 1971. Regulatory mechanisms of hemoglobin oxygen affinity in acidosis and alkalosis. J. Clin. Invest. 50: 700-706.

23. Scheinman, M. M., M. A. Brown, and E. Rapoport. 1969. Critical assessment of use of central venous oxygen saturation as a mirror of mixed venous oxygen in severely ill cardiac patients. Circulation. 40: 165-172.

24. Hutter, A. M., Jr., and A. J. Moss. 1970. Central venous oxygen saturations. Value of serial determinations in patients with acute myocardial infarction. J. Am. Med. Assoc. 212: 299-303.

25. Lichtman, M. A., M. S. Murphy, A. A. Whitbeck, and E. A. Kearney. 1974. Decreased oxygen binding to haemoglobin in subjects with hypoproliferative anaemia with and without chronic renal disease. Role of $\mathrm{pH}$. Br. J. Haemat. $27: 465$.

26. Hjelm, M. 1969. The content of 2,3-diphosphoglycerate and some other phospho-compounds in human erythrocytes from healthy adults and subjects with different types of anaemia. Forsvarmedicin. $5: 219-226$.

27. Valeri, C. R., and N. L. Fortier. 1969. Red-cell 2,3diphosphoglycerate an 1 creatine levels in patients with red-cell mass deficits or with cardiopulmonary insufficiency. N. Engl. J. Med. 281: 1452-1455.

28. Rørth, M., S. F. Nygaard, and H.-H. Parving. 1972. Effect of exposure to simulated high altitude on human 
red cell phosphates and oxygen affinity of hemoglobin. Influence of exercise. Scand. J. Clin. Lab. Invest. 29: 329-333.

29. Miller, M. E., M. Rørth, H. H. Parving, D. Howard, I. Reddington, C. R. Valeri and F. Stohlman, Jr. 1973. $\mathrm{pH}$ effect on erythropoietin response to hypoxia. $N$. Engl. J. Med. 288: 706-710.

30. Duhm, J., and E. Gerlach. 1971. On the mechanism of the hypoxia-induced increase of 2,3-diphosphoglycerate in erythrocytes. Studies on rat erythrocytes in vivo and on human erythrocytes in vitro. Pflügers Arch. Eur. J. Physiol. 326: 254-269.

31. Guest, G. M., and S. Rapoport. 1939. Role of acidsoluble phosphorus compounds in red blood cells in experimental rickets, renal insufficiency, pyloric obstruction, gastroenterities, ammonium chloride acidosis and diabetic acidosis. Am. J. Dis. Child. 58: 1072-1089.

32. Astrup, P., M. Rørth, and C. Thorshauge. 1970. Dependency on acid-base status of oxyhemoglobin dissociation and 2,3-diphosphoglycerate levels in human erythrocytes. II. In vivo studies. Scand. J. Lab. Clin. Invest. 26: $47-52$.

33. Astrup, P. 1970. Red cell $\mathrm{pH}$ and oxygen affinity of hemoglobin. N. Engl. J. Med. 283: 202-204.

34. Chillar, R. K., P. Slawsky, and J. F. Desforges. 1971. Red cell 2,3-diphosphoglycerate and adenosine tri- phosphate in patients with shock. Br. J. Haematol. 21: 183-188.

35. Desforges, J. F., and P. Slawsky. 1972. Red cell 2,3diphosphoglycerate and intracellular arterial $\mathrm{pH}$ in acidosis and alkalosis. Blood J. Hematol. 40: 740-746.

36. Alberti, K. G. M. M., P. M. Emerson, J. H. Darley, and T. D. R. Hockaday. 1972. 2, 3-diphosphoglycerate and tissue oxygenation in uncontrolled diabetes mellitus. Lancet. 2 : 391-395.

37. Duhm, J. 1973. 2,3-diphosphoglycerate metabolism of erythrocytes and oxygen transport function of blood. In Erythrocytes, Thrombocytes and Leukocytes. E. Gerlach, K. Moser, E. Deutsch, and W. Wilmanns, editors. Georg Thieme Verlag KG, Stuttgart. 149.

38. Oski, F. A., W. W. Miller, and M. Delivoria-Papadopoulos. 1970. The effects of deoxygenation of adult and fetal hemoglobin on the synthesis of red cell 2,3-diphosphoglycerate and its in vivo consequences. J. Clin. Invest. 49: 400-407.

39. Rossi, L. and F. J. W. Roughton. 1962. The difference of $\mathrm{pH}(\Delta \mathrm{pH})$ between reduced human haemoglobin and oxyhaemoglobin when equilibrated with the same pressure of carbon dioxide. J. Physiol. (Lond.). 162:17P-18P.

40. Oski, F. A., A. J. Gottlieb, M. Delivoria-Papadopoulos, and W. W. Miller. 1969. Red-cell 2,3-diphosphoglycerate levels in subjects with chronic hypoxemia. N. Engl. J. Med. 280 : 1165-1166. 